Aim of the study: To evaluate the inhibitory effect of 17 new analogues of FPh on the Pgp transport function, by estimation of the rhodamine 123 (Rod-123) accumulation inside cultured lymphocytes.

Material and methods: Lymphocyte were cultured in the presence of a lectin (PHA; $2 \%, v / v)$, incubated with benzo[ $\alpha]$ pyrene $(B[\alpha] P ; 7.5 \mu M, 48 h)$ to induce genotoxic damage and to increase Pgp expression in the cells. Lymphocytes cultured without the tested compounds were considered as controls.

Results: It was established that 10 analogues of FPh, among 17 tested, significantly increased Rod-123 accumulation in lymphocytes at the concentration of $10 \mu \mathrm{M}$. As compared to the control cultures the Pgp transport function was the most strongly inhibited by $1 \mathrm{a}, 1 \mathrm{~b}, 1 \mathrm{~d}$, $3 \mathrm{f}, 3 \mathrm{~h}$ and $3 \mathrm{i}$ analogues (approximately by $25 \%)$.

Conclusions: FPh analogues 1a, 1b, 1d, 3f, $3 \mathrm{~h}$ and $3 \mathrm{i}$ should be further studied as promising candidates for adjuvant cancer chemotherapeutics.

Key words: fluphenazine analogues, MDR, P-glycoprotein, MDR modulators.

\section{New fluphenazine analogues as inhibitors of P-glycoprotein in human lymphocyte cultures}

\author{
Agata Jaszczyszyn ${ }^{1}$, Kazimierz Gąsiorowski' ${ }^{1}$, Piotr Świątek ${ }^{2}$, \\ Wiesław Malinka², Katarzyna Cieślik-Boczula³, Joanna Petrus ${ }^{3}$, \\ Bogusława Czarnik-Matusewicz ${ }^{3}$
}

1Department of Basic Medical Sciences, Wrocław Medical University, Wrocław, Poland 2Department of Drug Chemistry, Wrocław Medical University, Wrocław, Poland ${ }^{3}$ Faculty of Chemistry, University of Wrocław, Wrocław, Poland

\section{Introduction}

Development of multidrug resistance (MDR) in cancer and in genotoxically damaged cells is the main reason for failure of cytostatic therapy [1]. MDR is defined as gradual lowering of sensitivity of neoplastic and/or genotoxically damaged cells to various cytostatic drugs, which develops in the course of a chemotherapy [2]. The mechanisms of MDR occurrence comprise the increase of cell-membrane transport, which leads to lower accumulation of cytostatic drugs inside cancer cells, the diminution of intracellular target enzyme affinity, the increase of metabolism and detoxification systems of cytostatic drugs, stimulation of the DNA repair systems and inhibition of apoptosis [1, 2].

The well-known mechanism responsible for MDR appearance is the increased expression of P-glycoprotein (Pgp) in neoplastic cells which leads to elevation of the energy-dependent transport of many drug molecules, including cytostatics, from the inner part of the cell membrane to the extracellular environment [2-4]. A decrease of cytostatic drug accumulation in a cytoplasm and occurrence of cell resistance to cytostatics appear as a result of Pgp overexpression [4, 5]. That is why the application to cancer chemotherapy of natural or synthetic compounds, able to inhibit the Pgp transport function, has been recognized as an effective strategy for restoration of sensitivity of neoplastic cells to cytostatic drugs $[1,6]$. These compounds, administered together with cytostatic drugs, markedly elevate intracellular accumulation and thereby raise their cytotoxic/cytostatic effects. Such compounds are called MDR modulators, and are recommended as adjuvant agents in neoplastic disease treatment [7, 8].

Phenothiazine derivatives belong to the group of MDR modulators; they are recognized as Pgp inhibitors. Fluphenazine (FPh), a drug from the phenothiazine family, for years has been used in psychopharmacotherapy [6, 8, 9]. Our previous research proved that in culture of genotoxically damaged cells FPh also significantly inhibited the transport function of Pgp [10]. It could be considered as a good adjuvant drug in cancer chemotherapy. However, its application in oncological therapy is limited by numerous undesirable effects on the central nervous system, even induction of drug-induced parkinsonism [11]. Therefore we have undertaken chemical syntheses to obtain new FPh derivatives exhibiting comparably strong chemopreventive activity as the parent FPh but possessing lower ability to pass through the blood-brain barrier.

The newly synthesized FPh analogues are characterized by lower lipophilicity value (logP) or a higher molecular weight (MW). Therefore it can be assumed that they should poorly penetrate into the central nervous system and will cause extrapyramidal symptoms to a lesser extent [12]. 


\section{Aim of the study}

The aim of this study was to estimate the effect of 17 newly synthesized FPh analogues on the inhibition of Pgp transport function in genotoxically damaged human lymphocyte cultures. It was our intention to identify analogues that are more effective than FPh in Pgp inhibition while also promising lower penetration through the blood-brain barrier to the central nervous system.

\section{Material and methods}

\section{Chemicals}

Phytohaemagglutinin, Minimum Essential Medium Eagle (MEM) and fetal calf serum were purchased from GIBCO (Gaithesburg, MD, USA). FPh-2HCl was obtained from Jelfa (Jelenia Góra, Poland), Rod-123 and all other reagents were obtained from SIGMA-ALDRICH (St. Louis, MO, USA). Lymphoflot and benzo $[\alpha]$ pyrene $(B[\alpha] P)$ were purchased from BioRad Medical Diagnostics (Dreieich, Germany) and Fluka (Buchs, Switzerland), respectively.

\section{Synthesis and properties of new FPh analogues}

New chemical FPh analogues were synthesized in the Department of Drug Chemistry (Wrocław Medical University). The chemical structures of FPh and its analogues are given in Table 1.

Estimations of physical properties of FPh and its analogues - lipophilicity expressed as the logP was calculated with the ChemPlus program from Hypercube, Inc., IBM PC version. The main physicochemical properties (MW, logP) of FPh and its analogues are provided in Table 2.

Detailed information concerning synthesis of new FPh analogues investigated in this work and their physicochemical and spectral properties are available exclusively on request (e-mail: wieslaw.malinka@am.wroc.pl).

\section{Lymphocyte separation from peripheral blood}

The research was approved by the Wrocław Medical University Ethics Committee. Heparinized venous blood (20 ml) was obtained by venipuncture from 5 volunteers, healthy, nonsmoking males, aged 20-26 years. Human lymphocytes were separated by the method of gradient centrifugation with Histopaque-1077 (Lymphoflot) [13]. The obtained mononuclear buffy coats were rinsed three times in MEM and monocytes were removed by the cell adhesion procedure. Lymphocytes were counted and viability of the cells was checked under a microscope after staining of the cell suspension with $0.4 \%$ trypan blue solution. The viability of isolated lymphocytes exceeded $90 \%$ of cells.

\section{Lymphocyte cultures}

Lymphocytes were seeded into 96-well plates at a density of $4 \times 10^{4}$ cells/well. Cells were grown in MEM containing $10 \%$ fetal calf serum and phytohaemagglutinin ( $2 \% \mathrm{v} / \mathrm{v})$ at $37^{\circ} \mathrm{C}$ in a humidified $\mathrm{CO}_{2}$ incubator. Cells were stimulated to increase the Pgp expression and to introduce genotoxic damage by incubation with benzo[ $\alpha]$ pyrene $(B[\alpha] P)(7.5 \mu \mathrm{M}$, $48 \mathrm{~h}$ ). Lymphocyte cultures kept in the presence of $B[\alpha]$ P without the tested compounds were used as controls. After pre treatment with $B[\alpha] P$ for $48 \mathrm{~h}$, cells were incubated with $10 \mu \mathrm{M} \mathrm{FPh}$ or its new analogues in culture medium at $37^{\circ} \mathrm{C}$ in $5 \% \mathrm{CO}_{2}$ for $2 \mathrm{~h}$.

\section{Rhodamine 123 accumulation assay}

The rhodamine 123 (Rod-123) accumulation test was used to estimate the effect of FPh and its chemical analogues on inhibition of the Pgp transport function activity [14]. Rod-123 is a substrate for Pgp, which substitutes many cytostatics transported by protein in the in vitro tests [14].

After incubation with tested compounds, lymphocytes were cultured with $5 \mu \mathrm{M}$ Rod-123 in culture medium, in the dark, at $37^{\circ} \mathrm{C}$ in $5 \% \mathrm{CO} 2$ for $60 \mathrm{~min}$. The fluorescence of intracellular Rod-123 accumulation was measured at $488-530 \mathrm{~nm}$ using Victor2 reader.

\section{Statistical evaluation}

Statistical analyses were performed using the program STATISTICA 9.1 PL. All experiments were repeated 5 times $(n=5)$. Values were expressed as mean, standard deviation (SD), minimal value, maximal value and median. $t$-test was applied to determine significant differences between the lymphocyte cultures.

\section{Results}

The effect of FPh and its 17 analogues on Pgp transport function in the tested lymphocyte cultures was estimated by measurement of fluorescence intensity of Rod-123 accumulated inside the cells, and was expressed as fluorescence arbitrary units (FAU). The results obtained in lymphocyte cultures with the tested compounds (E) were compared with the results in the control cultures (Eo) and defined as the E/Eo ratio; they are presented in histograms in Fig. 1.

The descriptive statistics and the statistical significance of the data shown in Fig. 1 are collected in Table 3.

Figure 1 and Table 3 show that among the 17 examined FPh analogues, 10 of them significantly $(p<0.05 ; p<0.01)$ increased the accumulation of Rod-123 (inhibited the transport function of Pgp) in lymphocyte cultures which were genotoxically damaged (with $B[\alpha] P$ ), in comparison with the control cultures. The greatest increase of Rod-123 accumulation, by $21-36 \%$ (on average by $25 \%$ ), was observed with analogues $1 \mathrm{a}, 1 \mathrm{~b}, 1 \mathrm{~d}, 3 \mathrm{f}, 3 \mathrm{~h}$ and $3 \mathrm{i}$. Depending on their inhibition of Pgp transport function, the examined FPh analogues can be ranged as follows: $3 \mathrm{i}>3 \mathrm{f}>1 \mathrm{~b}>3 \mathrm{~h}>1 \mathrm{a}=1 \mathrm{~d}$.

In the above series of experiments, the parent drug, FPh [10 $\mu \mathrm{M}$ ], did not significantly influence $(p>0.05)$ the Rod123 accumulation in the genotoxically damaged lymphocyte cultures.

\section{Discussion}

It is assumed that an effective chemosensitizing compound should inhibit the transport function of Pgp [15]. FPh belongs to the group of potential modulators of Pgp activity [16]. Our previous results showed that the FPh chemosensitizing effect was inversely proportional to its concentration in human lymphocytes cultures, genotoxically damaged by the model promutagen $\mathrm{B}[\alpha] \mathrm{P}[10]$. We found that FPh in low 
Table 1. Chemical structure of FPh and its analogues

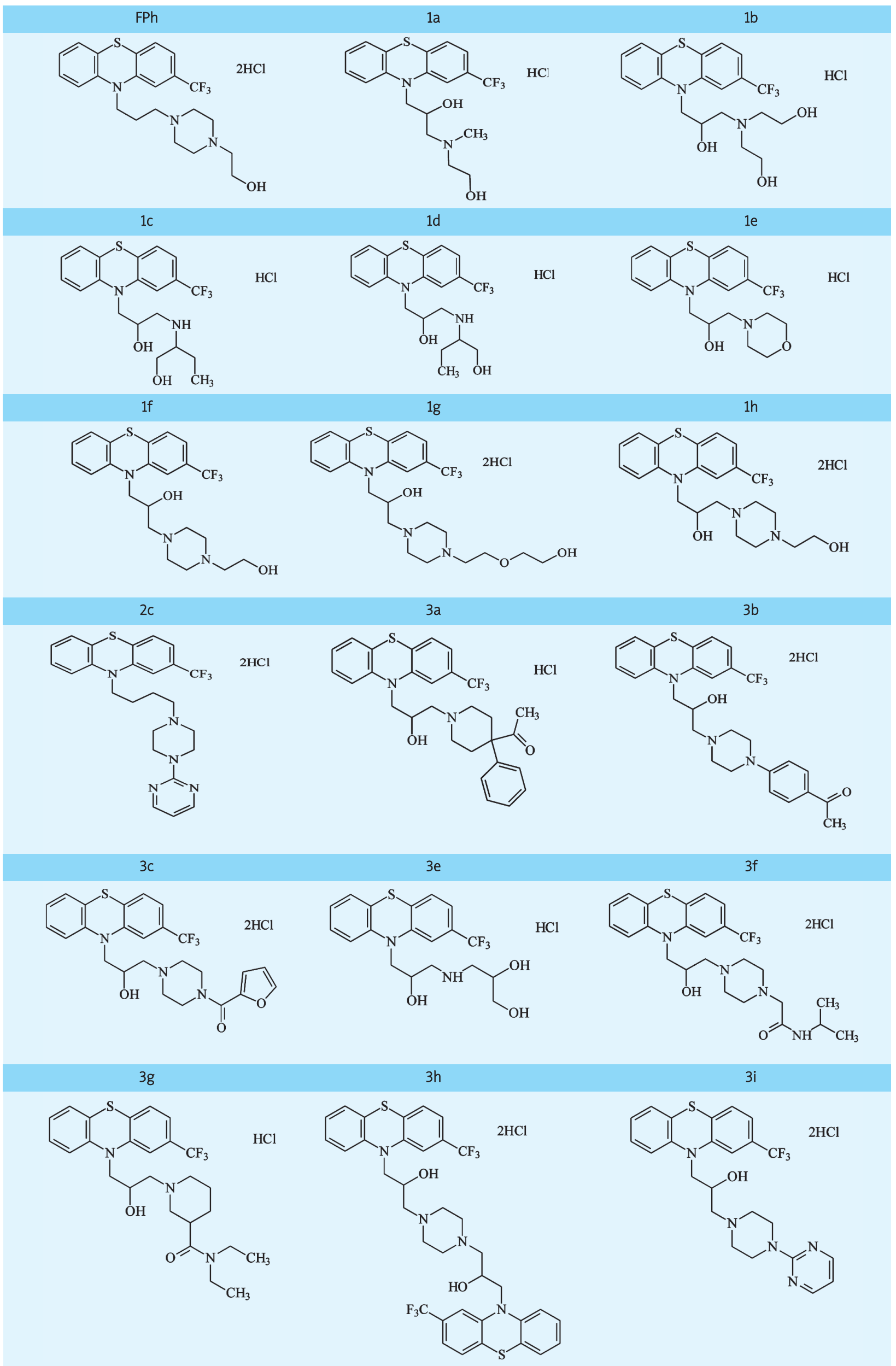


Table 2. Selected physicochemical properties of FPh and its analogues

\begin{tabular}{|c|c|c|c|}
\hline \multicolumn{2}{|c|}{ Tested compounds } & $\mathrm{MW}[\mathrm{g} / \mathrm{mol}]$ & $\log P$ \\
\hline \multicolumn{2}{|l|}{$\mathrm{FPh}$} & 510.4 & 3.42 \\
\hline \multirow{17}{*}{ analogues } & $1 \mathrm{a}$ & 434.90 & 3.32 \\
\hline & $1 b$ & 464.93 & 2.78 \\
\hline & $1 c$ & 448.93 & 3.84 \\
\hline & $1 d$ & 448.93 & 3.84 \\
\hline & 1e & 446.91 & 3.42 \\
\hline & $1 f$ & 453.52 & 3.12 \\
\hline & $1 g$ & 570.53 & 2.95 \\
\hline & $1 \mathrm{~h}$ & 526.52 & 3.12 \\
\hline & $2 c$ & 522.03 & 5.14 \\
\hline & $3 a$ & 563.07 & 6.64 \\
\hline & $3 b$ & 600.56 & 5.02 \\
\hline & $3 c$ & 576.50 & 3.19 \\
\hline & $3 e$ & 450.90 & 2.58 \\
\hline & $3 f$ & 581.56 & 3.63 \\
\hline & $3 g$ & 544.07 & 5.11 \\
\hline & $3 \mathrm{~h}$ & 805.72 & 7.16 \\
\hline & $3 i$ & 560.46 & 4.26 \\
\hline
\end{tabular}

concentration [0.125 $\mu \mathrm{M} ; 0.25 \mu \mathrm{M}]$ inhibited Pgp activity more strongly than in a concentration of $10 \mu \mathrm{M}$ or higher [10]. Moreover, it was observed that the effect depended on the cell cycle in the period of incubation with $\mathrm{FPh}[10 \mu \mathrm{M}]$ being statistically significant or insignificant $[10,17]$.

It can be surmised that FPh in a concentration over $10 \mu \mathrm{M}$ revealed an additional mechanism of impact on Pgp activity - together with direct interactions with the protein and/or its phosphorylation pathways, it also induced reorganization of the lipid environment of the cell membrane in the vicinity of Pgp. In the higher concentration of FPh [> $10 \mu \mathrm{M}$ ] we observed a cytotoxic effect of the drug, which could also be explained by the interaction of the drug with membrane lipids.
Therefore the FPh chemosensitizing activity and that of its 17 newly synthesized analogues in human lymphocytes cultures was tested in a concentration of $10 \mu \mathrm{M}$ and incubation time of 2 hours. In these incubation conditions toxic effects of the tested compounds on lymphocytes were not observed. The spectrofluorometric test of fluorochrome Rod123 retention enables one not only to examine the transport function of Pgp, but also to assess the real chemosensitizing effect [18].

Human lymphocytes are recommended in the literature for in vitro tests of Pgp activity, because they express Pgp, which is functionally similar to the transport protein in neoplastic cells with MDR phenotype [19]. Pre incubation of lymphocytes with $\mathrm{B}[\alpha] \mathrm{P}$ led to genotoxic damage and increased expression of Pgp in lymphocytes. Concentration [7.5 $\mu \mathrm{M}$ ] and the pre incubation time of $B[\alpha] P$ with model cells $[48 \mathrm{~h}]$ were previously experimentally assessed as well-tolerated by lymphocytes and inducing the expected effects.

The unwanted extrapyramidal side effects of FPh are the consequence of its accumulation in brain tissue and the interaction with dopaminergic receptors. To decrease the affinity of new analogues to dopaminergic receptors in the brain's nigrostriatal system, a hydroxylic group $(-\mathrm{OH})$ was introduced to a propyl bond $\left\{-\left(\mathrm{CH}_{2}\right)_{3}\right\}$, which connects nitrogen $(\mathrm{N})$, from the main phenothiazine tricyclic system, with an amine group in the side chain (Table 1) [20].

Only the $2 \mathrm{c}$ analogue did not have the - $\mathrm{OH}$ group in that place, but it had a butyl bond $\left\{-\left(\mathrm{CH}_{2}\right)_{4}\right\}$ instead of a propyl bond (Table 1) as the only one out of all the examined FPh analogues.

According to the literature data, the butyl bond in the compounds' structure from the phenothiazine group determines their ability to reverse MDR [21]. The results of our research did not confirm these results the $2 c$ analogue did not exhib-

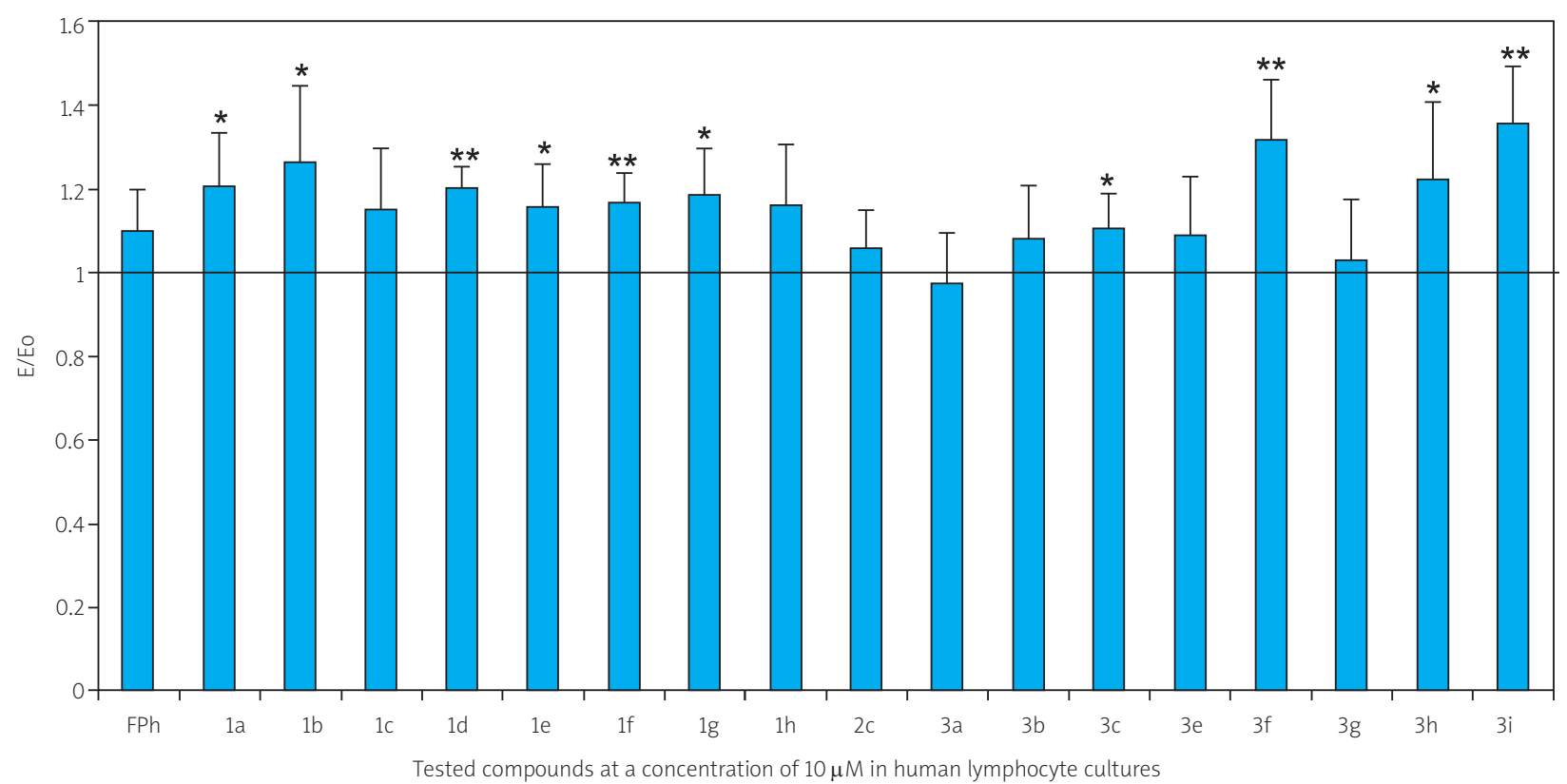

Fig. 1. Influence of FPh and its analogues (10 $\mu \mathrm{M}, 2 \mathrm{~h})$ on Rod-123 (5 $\mu \mathrm{M}, 60 \mathrm{~min})$ accumulation in human lymphocytes genotoxically damaged with $\mathrm{B}[\mathrm{a}] \mathrm{P}(7.5 \mu \mathrm{M}, 48 \mathrm{~h})$. The results obtained in the cultures with tested compounds (E) were compared with results obtained in the control cultures (Eo), and given as E/Eo ratios; mean $\pm \mathrm{SD}, n=5$. The control level is presented (E/Eo $=1$ ).

*significant $p<0.05 ;{ }^{* *}$ significant $p<0.01$ 
Table 3. Statistical analysis of the results obtained in the test of Rod-123 accumulation in the lymphocyte cultures

\begin{tabular}{|c|c|c|c|c|c|c|c|}
\hline \multirow{2}{*}{ Tested compounds } & & \multicolumn{4}{|c|}{$\begin{array}{l}\text { Rod-123 accumulation } \\
\text { [FAU] }\end{array}$} & \multirow[b]{2}{*}{ median } & \multirow[b]{2}{*}{$p$} \\
\hline & & $\begin{array}{l}\text { mean; } \\
n=5\end{array}$ & SD & $\begin{array}{l}\text { minimal } \\
\text { value }\end{array}$ & $\begin{array}{l}\text { maximal } \\
\text { value }\end{array}$ & & \\
\hline $\mathrm{FPh}$ & & 85 & 6.26 & 78 & 94 & 86 & 0.08 \\
\hline \multirow{18}{*}{ analogues } & $1 a$ & 93 & 9.94 & 83 & 105 & 89 & 0.021 \\
\hline & $1 b$ & 98 & 13.58 & 84 & 113 & 96 & 0.032 \\
\hline & $1 c$ & 89 & 8.87 & 74 & 97 & 90 & 0.059 \\
\hline & $1 d$ & 93 & 6.88 & 85 & 102 & 91 & 0.001 \\
\hline & 1e & 89 & 6.06 & 79 & 95 & 90 & 0.023 \\
\hline & $1 f$ & 90 & 4.44 & 84 & 95 & 90 & 0.005 \\
\hline & $1 \mathrm{~g}$ & 91 & 7.40 & 83 & 101 & 89 & 0.015 \\
\hline & $1 \mathrm{~h}$ & 89 & 7.19 & 81 & 98 & 88 & 0.065 \\
\hline & $2 c$ & 82 & 4.56 & 77 & 89 & 81 & 0.24 \\
\hline & $3 a$ & 75 & 7.46 & 69 & 88 & 72 & 0.66 \\
\hline & $3 b$ & 83 & 7.60 & 74 & 92 & 81 & 0.24 \\
\hline & $3 c$ & 86 & 8.56 & 74 & 96 & 86 & 0.045 \\
\hline & $3 e$ & 84 & 9.34 & 74 & 95 & 84 & 0.22 \\
\hline & $3 f$ & 101 & 6.83 & 94 & 109 & 98 & 0.006 \\
\hline & $3 f$ & 101 & 6.83 & 94 & 109 & 98 & 0.006 \\
\hline & $3 g$ & 79 & 10.26 & 65 & 87 & 86 & 0.67 \\
\hline & $3 h$ & 94 & 9.73 & 82 & 109 & 93 & 0.043 \\
\hline & $3 i$ & 104 & 8.93 & 91 & 112 & 109 & 0.003 \\
\hline control cultures & & 77 & 4.66 & 71 & 84 & 77 & - \\
\hline
\end{tabular}

it greater chemosensitizing activity in comparison to FPh and to its analogues (Fig. 1; Table 3).

Out of the 17 new FPh analogues $(10 \mu \mathrm{M})$, the strongest inhibitory effect on Pgp transport function in human genotoxically damaged lymphocyte cultures was established in the cases of compounds $1 \mathrm{a}, 1 \mathrm{~b}, 1 \mathrm{~d}, 3 \mathrm{f}, 3 \mathrm{~h}$ and $3 \mathrm{i}$. The greatest increase in Rod-123 accumulation in lymphocyte cultures was observed in the presence of analogues which contain a tertiary amine in the side chain: a piperazine amine (compounds $3 i$ and $3 f$ ) or aliphatic amine ( $1 \mathrm{~b}$ compound). The $1 d$ analogue also had a tertiary aliphatic amine in its side chain, but in comparison to the most active $1 \mathrm{~b}$ analogue it had fewer-OH groups in the side chain. Chemosensitizing activity, similar to $1 \mathrm{a}$ and $1 d$ analogues, had bisphenothiazine $-3 \mathrm{~h}$ analogue.

The obtained results showed that the chemosensitizing effect of the new FPh analogues depends on their chemical structure the presence of piperazine tertiary amine and the next amine groups, or the presence of aliphatic tertiary amine in the environment of at least three-OH groups seemed to be advantageous for blocking Pgp transport function and overcoming MDR. These observations determine further directions of chemical FPh compound modifications and the synthesis of its next analogues.

In conclusion, the search for new FPh analogues, effective Pgp modulators, is promising and should be continued. At the moment, the compounds $1 \mathrm{a}, 1 \mathrm{~b}, 1 \mathrm{~d}, 3 \mathrm{f}$, $3 \mathrm{~h}$ and $3 \mathrm{i}$ have been identified as good candidates for adjuvant agents in cancer chemotherapy.

This work was supported by the Polish Ministry of Sciences and Higher Education (Grant No. NN204 150338), Wroctaw Medical University (Grant No. 1945) and in part by the research fellowship within "Development programme of Wroclaw Medical University" funded by the European Social Fund, Human Capital, National Cohesion Strategy (contract no. UDAPOKL.04.01.01-00-010/08-01) and ST-413.

This paper was presented at the $3^{\text {rd }}$ Congress of Contemporary Oncology, Poznań, Poland, April 14-16, 2011.

\section{References}

1. Borowski E, Bontemps-Gracz MM, Piwkowska A. Strategies for overcoming ABC-transporters-mediated multidrug resistance (MDR) of tumor cells. Acta Biochim Polonica 2005; 52: 609-27.

2. Lenart K, Szyda A, Kiełbasiński M, Duś D, Podolak-Dawidziak M. Kliniczne skutki oporności wielolekowej w nowotworach. Onkol Prakt Klin 2005; 1: 18-26.

3. Mahadevan D, List AF. Targeting the multidrug resistance-1 transporter in AML: molecular regulation and therapeutic strategies. Blood 2004; 104: 1940-51.

4. Johanstone RW, Ruefli AA, Smyth MJ. Multiple physiological functions for multidrug transporter P-glycoprotein? TIBS 2000; 25: 1-6.

5. Guo X, Ma N, Wang J, et al. Increased p38-MAPK is responsible for chemotherapy resistance in human gastric cancer cells. BMC Cancer 2008; 8: 375-83.

6. Pająk B, Orzechowski A. Overview how adenocarcinoma cancer cells avoid immune- and chemotherapy-induced apoptosis. Adv Med Sci 2006; 51: 39-45.

7. Rodriguez I, Abernethy D, Woosley RL. P-glycoprotein in clinical cardiology. Circulation 1999; 99: 472-4.

8. Gąsiorowski K, Jaszczyszyn A. Fenotiazyny w paliatywnej terapii nowotworów. Onkol Pol 2008; 11: 167-72.

9. Takano M, Yumoto R, Murakami T. Expression and function of efflux drug transporters in the intestine. Pharmacol Ther 2006; 109: 137-61.

10. Jaszczyszyn A, Gąsiorowski K. Mechanizmy chemoprewencyjnego dziatania nowo syntezowanych analogów flufenazyny. Borgis, Warszawa 2006. 
11. Tugg LA, Desai D, Prendergast P, Remington G, Reed K, Zipursky RB. Relationship and side effects. Schizophrenia Res 1997; 25: 71-8.

12. Ambikanandan M, Genesh S, Aliasgar S, Shan SP. Drug delivery to the central nervous system: a review. J Pharm Sci 2003; 6: 252-73.

13. Boyum A. Separation of leukocytes from blood and bone marrow. Scand J Clin Lab Invest 1968; 21: 77-89.

14. Hien TT, Kim HG, Han EH, Kang KW, Jeong HG. Molecular mechanism of suppression of MDR1 by puerarin from Pueraria lobata via NF-KB pathway and cAMP-responsive element transcriptional activity-dependent up-regulation of AMP-activated protein kinase in breast cancer MCF-7/adr cells. Mol Nutr Food Res 2010; 54: 918-28.

15. Jaszczyszyn A, Gąsiorowski K, Świątek P, Malinka W. Proapoptotic activity of fluphenazine analogues after blocade sphingomyelinas es in cultures of human lymphocytes. Onkol Pol 2011; 14: 54-63.

16. Łachajczyk M, Procowska A, Ślusarska P, Reczuch B, Jaszczyszyn A. Badania modelowe in vitro aktywności chemoprewencyjnej flufenazyny. Flufenazyna w chorobie nowotworowej. W: Chory przewlekle - aspekty pielęgnacyjne, rehabilitacyjne, terapeutyczne. Rosińczuk-Tonderys J, Uchmanowicz I (red.). MedPharm Polska, Wrocław 2011; 207-18

17. Nasiłowska B. Geny oporności na leki. Postępy Nauk Med 2003; 3-4: 99-105.

18. Parasrampuria DA, Lantz MV, Benet LZ. A human lymphocyte based ex vivo assay to study the effect of drugs on |P-glycoprotein function. Pharm Res 2001; 18: 39-44.

19. Li H, Yan Z, Ning W, Xiao-Juan G, Cai-Hong Z, Jin-Hua J, Fang M, QingDuan W. Using rhodamine 123 accumulation in CD8+ cells as a surrogate indicator to study the P-glycoprotein modulating effect of cepharanthine hydrochloride in vivo. J Biomed Biotechnol 2011; 2011: 281651-7.

20. Jaszczyszyn A, Gąsiorowski K, Świątek P, Malinka W, Cieślik-Boczula K, Petrus J, Czarnik-Matusewicz B. Chemical structure of phenothiazines and their biological activity. Pharmacol Rep 2012; 64: 16-23.

21. Ford JM. Prozialeck WC, Hait WN. Structural features determining activity of phenothiazines and related drugs for inhibition of cell growth and reversal of multidrug resistance. Mol Pharm 1989; 35: 105-15.

\section{Address for correspondence}

\section{Agata Jaszczyszyn}

Department of Basic Medical Sciences

Wrocław Medical University

Kochanowskiego 14

51-601 Wroctaw

tel. +48713484310

e-mail: ludwig5@op.pl

Submitted: 7.12 .2011

Accepted: $\quad 7.05 .2012$ 